\title{
The Role of Engineering Teaching and Learning Fellows in The Transformation Process of ECE Courses
}

\author{
Deena Salem, and Brian Frank \\ Queen's University \\ deena.a.salem@queensu.ca
}

\begin{abstract}
This paper presents work in progress of a participatory action research project of transforming some Electrical and Computer Engineering (ECE) courses with the help of Engineering Teaching and Learning Fellows (ETLF). The objective of this paper is to highlight the effectiveness of incorporating an ETLF, with expertise in both the engineering and education fields, in the process, and their accountability throughout the three phases: pre-transformation, transformation and post-transformation.
\end{abstract}

Keywords: Participatory action research, Electrical and Computer Engineering, Engineering Teaching and Learning Fellows, Engineering Education, transformation, Changelab, TRESTLE.

\section{INTRODUCTION}

Recent rapid of technological advances have raised the expectations of licensing and regulatory bodies, and employers for engineering graduates in the 21 st century. Special attention was given to the electrical and computer field, who are regarded as the propellers of the perpetually evolving technology. To meet these expectations, the pedagogical content of the engineering courses - including subject matter, delivery, and assessment processes — should be reviewed and updated on a regular basis, to align the learning outcomes of different courses to the continuously evolving program learning outcomes.

In almost all universities there is usually an established teaching and learning entity which is responsible for supporting the development and transformation of different courses in diverse disciplines. The novelty in this study is to embed Engineering Teaching and Learning Fellows (ETLF), with PhD degree in Electrical and Computer Engineering, formal pedagogy training, and diverse higher education teaching experience, in the department to support the courses transformation with an emphasis on the effectiveness of the instructional strategies that enhance the students' engagement and their employability skills.

This study is part of two major projects: a) Engineering Change Lab [2], b) The Transforming Education, Supporting Teaching and Learning Excellence (TRESTLE) [3], whose concern is to augment the current teaching activities with active learning techniques that increases the students' engagement.
"Engineering Change Lab" is a nation-wide project which involves a network of 100 stakeholders from diverse Canadian engineering programs, industrial and governmental entities that are concerned with enhancing engineering education and its impact on the profession. These stakeholders and key team players have formed the network that initiated the change process, and are inviting more participants in the field to get involved.

TRESTLE is a 7-institution NSF-funded project, including Queen's University, to support improvements in undergraduate STEM education through supporting course design projects, enhancing educational expertise in departments, and building communities within and across campuses to enhance the impact of local experts and to enhance the collaboration between institutions involved to share the results to be able to implement the same interventions to improve the learning experiences for their students.

In this paper, a participatory action research method is used to study how an ETLF would impact the development of ECE courses.

\section{CONTRIBUTIONS OF AN ETLF TO THE TRANSFORMATION PROCESS}

The process includes three consecutive phases that integrate to shape the overall process: pretransformation, transformation, and post-transformation.

\subsection{Pre-Transformation Phase}

The role of the ETLF in this phase is to elicit instructors' and students' perceptions of the teaching and learning process in the department, perform courses document analysis, and plan data collection strategies which include: observations of lectures, laboratories and tutorials of the targeted courses, students focus groups, and instructors' interviews.

\subsection{Transformation Phase}

As per the findings of the data analysis, the ETLF's role in this phase is to provide instructors with evidencebased instructional methods, as well as best practices alternative assessment activities. These align with the courses learning outcomes to help enhance the effectiveness of the teaching/learning processes, which shapes the core of the transformation process. These methods may range from minor modifications in the 
delivery of the course, such as using clickers, to revamping the course.

\subsection{Post-Transformation Phase}

After the implementation of the intervention, the ETLF role is to elicit and analyze the post-delivery feedback of both the faculty and the students, and implements the recommended modifications in the next iterations of the transformation process. Results of every iteration will be documented and will contribute to the final analysis of the transformation process. To sustain and invest the efforts and experience gained in the transformation process, the ETLF should set a propagation plan [1] for successful interventions and identify potential adopters on the departmental level.

\section{INSTRUCTORS' PERCEPTIONS OF THE ETLF}

The inquiry that may emerge when discussing contributions of the ETLF in the courses development is: Isn't it easier if the instructors to take the responsibility of reviewing and transforming their courses? The author's response to this question is yes, it is definitely possible, but an ETLF has more to offer. ETLF can support the instructors and facilitate the process, which can be achieved by combating the following limitations: time scarcity, courses connectivity, and biasedness.

\subsection{Time Scarcity}

Faculty members and instructors in higher education institutions are usually evaluated according to their research activities and publications, with less focus on teaching excellence and pedagogical innovations. There is always a trade-off between research and teaching activities [4 and 9], which burns the instructors out or limits the development process of different courses. ETLF who are available to support the instructors have the time needed for the transformation, which allows them to plan the whole process, negotiate it with the instructor, and support different phases of the process.

\subsection{Courses Connectivity}

The course instructor is usually the expert in the technical field. Meanwhile, the instructor may not possess the same level of expertise in different courses in the program, and the connectivity required between different courses. As for the ETLF who holds an ECE Engineering PhD. in addition to theoretical and practical education training has the interdisciplinary and overarching perspectives of the program and its learning objectives which allow them to align the courses' learning outcomes with those of the program.

\subsection{Biasedness}

As mentioned in section 2 of this paper, both the preand post-transformation processes include the perspectives and opinions of students, TAs and instructors. Faculty members and instructors can moderate the focus groups and interviews, and add their reflections and feedback throughout the process. However, doing this might impose a biasedness which might alter the findings of the study and thus obviate the advantages expected from the transformation process.

The ETLF provides a safe space for different stakeholders, which enhances the effectiveness of the findings of the study.

\section{METHODOLOGY}

The research presented in this paper explores the role of the ETLF involved in transforming selected ECE undergraduate courses. In this section, the participatory action research [5-8], will be discussed while highlighting the contribution of different participants in the research.

\subsection{Participatory Action Research (PAR)}

PAR is a spiral approach that includes recurrent phases of planning, action, reflection, and evaluation, in which participants are engaged in the research process [8] to determine the direction and goals of change, which distinguishes PAR from the action research [6], widely used in educational research.

Nod Miller [5] describes his own experience using PAR: "--participatory action research is fulfilling, frustrating, messy, confusing, and exciting-just like "real life," in fact. It is also difficult to contain within clear time boundaries. Since the research is explicitly concerned with the promotion of change, the process continues beyond the time and space in which participants are explicitly engaged in the work. Although definition is difficult and the process is hard to capture and delineate, participatory action research offers potential for its practitioners to reach understandings about the complexity of experience and to develop strategies for change." [pp.79]

Table 1 shows different phases and the action(s) correlated to each phase.

Table 1: Typical key stages in PAR [9].

\begin{tabular}{|l|l|l|}
\hline$\#$ & Phase & \multicolumn{1}{c|}{ Action } \\
\hline 1 & Action & $\begin{array}{l}\text { Establish relationships and } \\
\text { common agenda with all } \\
\text { stakeholders. Collaboratively } \\
\text { decide on issues. }\end{array}$ \\
\hline 2 & Reflection & $\begin{array}{l}\text { On research design, ethics, } \\
\text { knowledges and accountability. }\end{array}$ \\
\hline 3 & Action & $\begin{array}{l}\text { Build relationships. Identify roles } \\
\text { and responsibilities. Collectively }\end{array}$ \\
\hline
\end{tabular}




\begin{tabular}{|l|l|l|}
\hline & & $\begin{array}{l}\text { design research processes and } \\
\text { tools. Discuss potential outcomes }\end{array}$ \\
\hline 4 & Reflection & $\begin{array}{l}\text { On research questions, design, } \\
\text { working relationships and } \\
\text { information required }\end{array}$ \\
\hline 5 & Action & $\begin{array}{l}\text { Work together to implement } \\
\text { research and collect data. Enable } \\
\text { participation of all members. } \\
\text { Collaboratively analyse findings. } \\
\text { Collaboratively plan future actions }\end{array}$ \\
\hline 6 & Reflection & $\begin{array}{l}\text { On working together. Has } \\
\text { participation worked? What else } \\
\text { do we need to do? }\end{array}$ \\
\hline 7 & Action & $\begin{array}{l}\text { Begin to work on feeding research } \\
\text { back to all participants and plan for } \\
\text { feedback on process and findings }\end{array}$ \\
\hline 8 & Reflection & $\begin{array}{l}\text { Evaluate both the action and } \\
\text { reflection processes as a whole }\end{array}$ \\
\hline 9 & Action & $\begin{array}{l}\text { Collectively identify future } \\
\text { research and impacts }\end{array}$ \\
\hline
\end{tabular}

Phases mentioned in Table 1 can be mapped to reflect the accountability of different stakeholders in the PAR. In the following section, I will discuss different phases I experienced in the transformation process of some of the ECE courses, and the accountability of different stakeholders.

\subsection{PAR in Courses Transformation}

The ETLF share the accountability with the course instructors, department and faculty heads, throughout the three phases of the courses transformation process, Tables 2-4.

4.2.1 Pre-transformation. In this phase, as shown in Table 2, the ETLF share the accountability with other stakeholders, but has the responsibility of setting the stage for the transformation. It starts by establishing relationships and trust with all stakeholders, which enables instructors and faculty members to explore what the ETLF offers to enhance students' learning. For the students, the ETLF can offer them a safe space that allows them to reflect on their learning experiences with a focus on how their experiences meet their expectations, and where they would like to experience improvement.

It is these relationships that allow stakeholders of the teaching and learning process to share a common understanding and vision of improvement needed. The ETLF is responsible for identifying the roles and accountability of different stakeholders in the plan agreed upon and to follow up the progress of different phases of the process, and if further interventions are required.

Plan of data collection is the responsibility of the ETLF, and it includes content analysis, observations, focus groups, interviews, and surveys.
Table 2: Accountability of different stakeholders in the pre-transformation phase

\begin{tabular}{|l|l|c|}
\hline \multicolumn{1}{|c|}{ Action } & Accountability \\
\hline \multirow{4}{*}{$\begin{array}{l}\text { Establish relationships } \\
\text { and common agenda with } \\
\text { all stakeholders. }\end{array}$} & ETLF \\
\hline $\begin{array}{l}\text { Collaboratively decide on } \\
\text { issues }\end{array}$ & ETLF/stakeholders \\
\hline $\begin{array}{l}\text { On research design, } \\
\text { ethics, knowledges and } \\
\text { accountability. }\end{array}$ & ETLF \\
\hline $\begin{array}{l}\text { Discuss potential } \\
\text { outcomes }\end{array}$ & ETLF/Instructors \\
\hline $\begin{array}{l}\text { Identify roles and } \\
\text { responsibilities. }\end{array}$ & ETLF \\
\cline { 2 - 3 } $\begin{array}{l}\text { Collectively design } \\
\text { research processes and } \\
\text { tools. }\end{array}$ & ETLF/Stakeholders \\
\hline $\begin{array}{l}\text { On research questions, } \\
\text { design, working } \\
\text { relationships and } \\
\text { information required }\end{array}$ & ETLF \\
\hline \multirow{2}{*}{$\begin{array}{l}\text { On working together. Has } \\
\text { participation worked? } \\
\text { What else do we need to } \\
\text { do? }\end{array}$} & ETLF/Stakeholders \\
\hline $\begin{array}{l}\text { Work together to } \\
\text { implement research and } \\
\text { collect data }\end{array}$ & \\
\hline $\begin{array}{l}\text { Enable participation of all } \\
\text { members. }\end{array}$ & ETLF/stakeholders \\
\hline $\begin{array}{l}\text { Collaboratively analyse } \\
\text { findings. }\end{array}$ & ETLF/instructors \\
\hline \multirow{2}{*}{} & ETLF \\
\hline
\end{tabular}

4.2.2 Transformation. In this phase, as shown in Table 3, the ETLF's role is to implement the plan, share the accountability with other stakeholders, and set the transformation plan and allocate the resources needed to implement it.

Table 3: Accountability of different stakeholders in the transformation phase

\begin{tabular}{|c|c|c|}
\hline & Action & Accountability \\
\hline \multirow{2}{*}{ 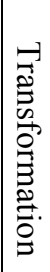 } & Collaboratively plan & ETLF/stakeholders \\
\hline & $\begin{array}{l}\text { On working together. Has } \\
\text { participation worked? } \\
\text { What else do we need to } \\
\text { do? }\end{array}$ & ETLF \\
\hline
\end{tabular}

4.2.3 Post-transformation. In this phase, as shown in Table 4, the ETLF share the accountability with other stakeholders, and study the post-delivery feedback of the instructors and the students.

Table 4: Accountability of different stakeholders in the post-transformation phase 


\begin{tabular}{|c|c|c|}
\hline & Action & $\begin{array}{c}\text { Accountabilit } \\
\mathbf{y}\end{array}$ \\
\hline \multirow{3}{*}{ 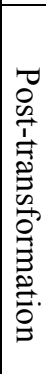 } & $\begin{array}{l}\text { Begin to work on feeding } \\
\text { research back to all } \\
\text { participants and plan for } \\
\text { feedback on process and } \\
\text { findings }\end{array}$ & ETLF \\
\hline & $\begin{array}{l}\text { Evaluate both the action and } \\
\text { reflection processes as a whole }\end{array}$ & ETLF \\
\hline & $\begin{array}{l}\text { Collectively identify future } \\
\text { research and impacts }\end{array}$ & $\begin{array}{l}\text { ETLF/stakehol } \\
\text { ders }\end{array}$ \\
\hline
\end{tabular}

\section{SUMMARY}

In this paper, I presented work in progress of a participatory action research transformation project of Electrical and Computer Engineering (ECE) courses with the help of an Engineering Teaching and Learning Fellows (ETLF). The main objective of this paper is to highlight the effectiveness of incorporating an ETLF with expertise in both the engineering and education fields. The paper also shows how ETLF adds to the process, and how their role varies throughout the three phases: pre-transformation, transformation and posttransformation.

\section{Acknowledgements}

I thank the stakeholders in FEAS, Queen's University specially the members of the ECE for their tremendous collaboration in the process of transformation of the targeted courses, which made my task enjoyable, fulfilling and rewarding. Special thanks to the students who volunteered in every stage of the process to give me their insights on their learning experience in the department.

\section{References}

[1] Henderson, C., Cole, R., Froyd, J., Gilbuena, D., Khatri, R., \& Stanford, C. Designing Educational Innovations for Sustained Adoption: A How-to Guide for Education Developers Who Want to Increase the Impact of their Work. Springer, 2015.

[2] https://www.ewb.ca/en/venture/engineering-change-lab/

[3] http://www.colorado.edu/cs1/trestle-0

[4] James R. Lackritz, "Exploring burnout among university faculty: incidence, performance, and demographic issues." Teaching and teacher education, vol. 20, no.7, pp.713-729, July 2004.

[5] Miller, Nod. "Participatory action research: Principles, politics, and possibilities." New Directions for Adult and Continuing Education 1994.63 (1994): 69-80.

[6] Norton, Lin S. Action research in teaching and learning: A practical guide to conducting pedagogical research in research in universities. Routledge, 2009.

[7] Rachel Pain, Geo Whitman and David Milledge, Report Participatory Action Research Toolkit: An Introduction to Using PAR as an Approach to Learning, Research and Action, Durham University \& Lune Rivers Trust, 2010, 3 p. Available from

https://www.dur.ac.uk/resources/beacon/PARtoolkit.pdf

[8] Sara Kindon, Rachel Pain, and Mike Kesby, eds. Participatory action research approaches and methods: Connecting people, participation and place. Routledge, 2007.

Sellers-Rubio Ricardo, Francisco J. Mas-Ruiz, and Ana B. Casado-Díaz, "University Efficiency: Complementariness versus Trade-off between Teaching, Research and Administrative Activities," Higher Education Quarterly, vol. 64. no. 4, pp. 373-391, Oct. 2010 